\title{
THE NEW TESTAMENT MOSES IN THE CONTEXT OF ANCIENT JUDAISM ${ }^{1}$
}

\author{
John D. Lierman
}

This study is an assessment of how the New Testament, set within the context of ancient Judaism, characterizes the functions of Moses in relation to Israel and the Jewish people. Although the study focuses primarily on NT texts, other ancient writings and historical material are consulted so as to situate the NT Moses in the larger milieu of Jewish thought.

The primary aim of this study is to contribute to the knowledge of NT-period Judaism by broadening understanding of the ancient Jewish conception of Moses. Second, the thesis thereby places the study of Moses Christology on better ground. Third, the study of a theme important to both Jews and Christians offers the opportunity to compare Christian and Jewish interpretation of the Old Testament. Fourth, because the study focuses particularly on the relations understood to exist between Moses and Israel the study also lays the groundwork for further investigation of early ecclesiology, which is known to derive in part from Jewish self-conception.

The Introduction to the thesis includes a survey of modern study of the presentation of Moses in the New Testament and in Jewish and Graeco-Roman writings. Following the Introduction, the thesis proceeds thematically, beginning with an examination of some roles of Moses that, while sometimes recognised, are not always properly appreciated.

Chapter Two, which treats 'Moses as Prophet', focuses on the exceptional eminence credited to Moses in this role, and on the conformity of his NT description to contemporary Jewish prophetic ideals.

In the context of ancient Judaism, Moses was not just a prophet he

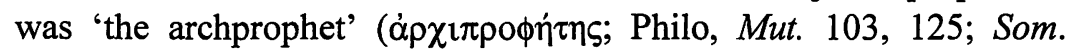
2.189). Deuteronomy 18:15-19, thought in NT times to have announced the establishment of the institution of prophecy in Israel,

1 J.D. Lierman, The New Testament Moses in the Context of Ancient Judaism (Ph.D., University of Cambridge, 2002); supervisor: Professor W. Horbury. 
specifically founded it on the ministry of Moses. Eventually the Rabbis were to teach that the prophecy of Moses encompassed all that was ever prophetically revealed.

The New Testament implies or assumes the prophethood of Moses in a handful of texts, including John 1:45; 5:46; and Act 7:20-39, and mentions it explicitly in Acts 3:22-26. Additionally, Moses receives the title of mediator in Galatians 3:19 in connection with his prophesying the Law. A special focus of this Chapter is the reference in Acts 7:36 to the 'wonders and signs' of Moses. The miracles worked by Moses, which undoubtedly served in earlier times to confirm his credentials as God's emissary, seem likely in the first century $\mathrm{AD}$ to have been read as distinctively prophetic acts.

Chapter Three, 'Moses as Priest and Apostle', examines two themes which are represented in the New Testament only briefly, in Hebrews $3: 1-6$, but which cut a much larger profile in contemporary extra-NT literature.

The priesthood of Moses, taken for granted in rabbinic literature, is also important to first-century Jewish writers. Its sole NT appearance, where the priesthood of Moses provides the jumping-off point for discussion of the priesthoods of Aaron and Melchizedek, points to at least one Christian community that held this common view of Moses.

Hebrews $3: 1-6$ seems to be the earliest extant reference to the apostleship of Moses; his apostleship, however, explicitly appears in (other) Jewish writings from after the NT period, where he is God's שליח. This, combined with the existence, before and after the NT period, of Jewish officials called apostles, suggests a non-Christian, Jewish background to Hebrews's application of the term to Moses. The evidence for Jewish ascription to Moses of both priesthood and apostleship, combined with the absence of further Christian references to Jesus as apostle, suggests that the depiction of Jesus in Hebrews as apostle and high priest is derived from older Jewish ideas about Moses.

In the NT period, many looked back to Moses as Israel's first king; Chapter Four pursues this theme into the New Testament itself. Both Greek and Semitic interpretative traditions show that texts such as Exodus 4:20 and Deuteronomy 33:5 and even Deuteronomy 18:15 were taken to teach that Moses had been a king; other Jewish literature also carries the tradition, or interacts with it.

In the New Testament, Acts 7:35 can be read as an explicit statement that Moses was king, while the feeding narratives of Mark 6:34-44 and John 6:1-15 are saturated with allusions to his kingship. 
To these can be added once again Hebrews 3:1-6; intricate allusions to various OT and targumic texts found there can perhaps only be satisfied by invocation of Moses as a (priest-)king. In all these passages the best, or perhaps the only, sense that can be made depends on Moses being recognised both by author and by reader as a king.

Chapter Five develops a Jewish interpretative context for 'the Baptism into Moses' of 1 Corinthians 10:2.

The baptism into Moses is best read as an echo of a Jewish piety which saw in Moses a unifying and spiritual figure, even someone into whom his followers could be baptized. Evidence for such a view of Moses arises not just in Philo and other Alexandrian literature, but also in texts generally thought to have a Palestinian provenance, such as Josephus, the Assumption of Moses, the Biblical Antiquities, and Paul. This is accompanied by other evidence which strongly suggests that there was extant in Paul's day a Jewish rite, probably involving the baptism of proselytes, which could easily wear the label, 'baptism into Moses'. The findings of this chapter thus even suggest that Paul's doctrine of baptism into Christ may partially be indebted to the baptism into Moses, and not the other way round.

Chapter Six, 'Moses as Lawgiver', turns to probably the most familiar, yet possibly the most misconstrued, element of Moses' ministry to Israel. It is shown that Jewish traditions of the NT period, including the New Testament itself, break into two main streams, one of which saw Moses principally as a transmitter of the Law, and the other as its maker.

The Synoptic Gospels contain traditions which ascribe a great deal of authority to Moses personally. On the other hand, Moses does not seem to have been especially important for Paul, despite his interest in the Law; his two main references to Moses (2 Cor. 3; Gal. 3:19) depict Moses as a mediator, not a legislator, a position that became the standard rabbinic view. John's Gospel portrays conflict over how Moses ought to be viewed, with the narrator, and the narrator's Jesus, apparently viewing Moses essentially as a mediator, while a 'popular' view locates in Moses not only the power to work wonders (Jn. 6:3132), but also the authority of the Law he gave (Jn. 5:45-47; 7:16-24).

Chapter Seven, 'Moses the Focus of Jewish Faith and Loyalty', argues that Moses appears in the New Testament and other Jewish writings as a personal focus of Jewish allegiance and belief.

The notion of faith in Moses, or of Moses as someone to be believed in, starts from explicit biblical tradition (Ex. 14:31) and survives in a variety of traditions before and after the NT period. 
Within the New Testament itself Jews are described as disciples of Moses, Moses appears as someone who can be preached, blasphemed, or believed in, and lapsing from Judaism is described as apostasy from Moses. All these motifs find analogues in extra-NT material. The accumulation of offices and functions to Moses noticed in the previous chapters of this study, references to Moses in Qumran and elsewhere as (some kind of) a divine or angelic figure, and the description of Moses as an effective overseer and personal authority over the Jews, all seem to work together to establish Moses as a personal focus for Jewish allegiance and trust.

Chapter Eight, finally, presents points of contact between the Moses of the New Testament and the NT presentation of Christ.

Although Moses Christology has not been totally ignored up until now, scholars have tended to work with an incompletely realised picture of Moses, which has in turn tended toward the undue minimisation of the role of Moses in early Christology. Moses, however, was a large and luminous figure who stood at the centre of Jewish identity and piety. Christians, in marking out their claims for Christ, consciously posed Christ as the heir to the claims of preeminence made for Moses. Perhaps most notably, pre-Christian Judaism possessed in some sense a binary focus of loyalty-God and his servant Moses; this finding is corroborated in other Jewish literature of the period, but the NT writings provide some of the clearest characterisations of Moses as something like the head of the Jewish church. It seems likely that Jesus was seen as a Mosaic Messiah in senses heretofore not properly appreciated.

To conclude, while the portrait of Moses that emerges from the New Testament is generally consistent with that arising from other ancient Jewish writings, at the same time the New Testament also contributes important new insights into how Jews believed Moses functioned toward them, and into how they characterised their relationship with him. The NT Moses forms an under appreciated key to NT Christology and ecclesiology, especially to the Christian conception of the relationship between Christ and the Church. 